\title{
Saving lives with fewer discussions - coordination between military and non-military organisations during disaster relief operations
}

\author{
Johan STEVENS, Janjaap SEMEIJN, Cees J. GELDERMAN \\ Open University of The Netherlands, The Netherlands
}

\begin{abstract}
:
Purpose: This study focusses on the coordination required between military and non-military organisations during humanitarian disasters.

Design / Research methods: An in-depth case study was conducted of the disaster relief operation after hurricane Matthew on Haiti in October 2016. We investigated the support of the Dutch military organization and its coordination with the non-military relief organizations. We examined coordination issues at operational, tactical, and strategic levels.
\end{abstract}

Findings: The study shows that no coordination problems occurred at operational level. At the tactical level, cultural differences between military and non-military organizations resulted in coordination problems and deviant perspectives on urgency. At the strategic level, there was a disagreement between the Dutch Ministry of Foreign Affairs and the Dutch Ministry of Defence regarding the Oslo Guidelines. A minority agreed that the guidelines actually apply to military organizations during disaster relief operations.

Practical implications: The coordination between the military organization and the non-military relief organization during disaster relief operations can be improved by promoting common and mutual respect and defining a clear tasks and role fulfilments. A first step to improve the coordination is to get familiarity and clarity on the Oslo Guidelines. Another step for improvement is for the military organization to accept that it has no leading but an assistance role during disaster relief operations.

Research limitations/implications: A single case study limits the external validity of the results, although useful insights were gained. Future research could address the role of the Oslo Guidelines during disaster relief operations. Are these guidelines still valid, should they be updated, and are the sufficiently known by all relief organizations, including the military?

Correspondence address: Johan Stevens, Janjaap Semeijn, Cees J. Gelderman, Open University of The Netherlands, Postbus 2960, 6401DL Heerlen, The Netherlands. E-mail: j.stevens.01@mindef.nl, janjaap.semeijn@ou.nl, kees.gelderman@ou.nl

Received: 11.06.2018, Revised: 18.03.2019, Accepted: 23.04.2019

doi: http://dx.doi.org/10.29015/cerem.738 
Originality/value of the article: The world is faced with an increasing occurrence of disasters affecting human lives. More lives could be saved when military and non-military organizations would work together more effectively. This is one of the first studies to explore the terms of engagement at the start of relief operations.

Keywords: humanitarian disasters, disaster relief operations, military and non-military coordination, humanitarian logistics

JEL: $M 4$

\section{Introduction}

We In the past two decades, the world has faced more than a thousand disasters. The Centre for Research into the Epidemiology of Disasters (CRED) reported in 2016 that from 2005 till 2014 an annual average of 367 disasters affected 76 thousand humanitarian losses per year. In 2016 even more than 471 disasters were registered (CRED 2016). Based on the observed upward trend in the last hundred years, natural disasters are expected to increase fivefold in the next 40 years (Thomas, Kopczak 2005).

The main goal of a (humanitarian) supply chain in the response phase of a disaster is to respond in an agile manner to save as many lives as possible and to ease the suffering of vulnerable people. In order to mitigate the impact of a natural disaster, effective and efficient logistics preparation and response are needed (Tatham, Houghton 2011). To achieve this objective, the logistical effort of both military and non-military relief organizations needs to be coordinated (Fernandez, Suthikarnnarunal 2011). The response increasingly requires coordination and task specialization between (humanitarian) relief organizations, as well as coordination with and between the military, governments and private businesses (Van Wassenhove 2006).

In general, there has been much criticism on the disaster relief community for its lack of coordination (McLachlin, Larson 2011). The increasing number of relief organizations tend to work separately (Van Wassenhove 2006), in spite of common goals (Thomas, Kopczak 2005). The lack of coordination is considered one of the 'wicked problems' of humanitarian logistics, referring to decisions with multiple requirements and stakeholders, where there is no agreement on the solution or even the problem (Tatham, Houghton 2011). In 2017, Irma was an extremely powerful 
and catastrophic hurricane. Media criticized the UK, French and Dutch governments for responding too slow and not doing enough to help the victims. The Situation Report No. 6 by the UN Office of the Coordination of Humanitarian Affairs concluded that the severely limited communications were "hampering the coordination of relief suppliers".

One of the reasons for the lack of coordination is that disaster relief can be characterised as a competitive environment. Within a disaster relief setting, (humanitarian) relief organizations may simultaneously coordinate and compete with each other. Humanitarian relief organizations compete for donors, resources, media attention and local networks, discouraging them to invest in coordinative efforts (Altay, Labonte 2014; Hicks, Pappas 2006). Military organizations are not the perfect partners for the relief organizations. The difference in origin, cultural and political nature of these organizations poses issues in coordination (Van Wassenhove 2006).

The number of studies on coordination in the field of humanitarian and disaster relief is increasing. Studies investigated the horizontal cooperation between humanitarian organizations (Schulz, Blecken 2010), cooperation in humanitarian logistics through clusters (Jahre, Jensen 2010). Coordination between organizations works better when the (different) roles of these organizations are clear to all the participants (Jensen, Hertz 2016). Growing attention is given to the coordination between military and non-military relief organization during disaster relief operations (e.g. Rietjens et al. 2008; Fernandez, Suthikarnnarunai 2011; Barber 2012; Heaslip, Barber 2014; Tatham, Rietjens 2016).

For an effective and efficient disaster relief operation, organizations must coordinate their efforts on every (organizational) level. More lives can be saved when military and non-military organizations work together more effectively. Therefore, this study explored the terms of engagement and the coordination between military and non-military organizations during a disaster relief operation. An in-depth case study is conducted of the disaster relief operation after hurricane Matthew on Haiti in October 2016. We investigated the support of the Dutch military organization and its coordination with the non-military relief organizations at operational, tactical, and strategic levels. 


\section{Literature review}

\subsection{Disasters and humanitarian logistics}

This study focusses on "sudden-onset natural disasters" (see Table 1). The time before, during and after the occurrence of a disaster can be divided in different phases. The commonly used model for emergency management consists of four main phases: mitigation, preparedness, (immediate) response, and the recovery phase (Altay, Green 2006; Leiras et al. 2014; Ahmadi et al. 2015). Given the role of the military in this study, we will address the latter two phases: the immediate response and recovery.

\section{Table 1. Types of disaster}

\begin{tabular}{|c|c|c|}
\cline { 2 - 3 } \multicolumn{1}{c|}{} & Natural & Man-made \\
\hline Sudden-onset & $\begin{array}{c}\text { Earthquake } \\
\text { Hurricane }\end{array}$ & $\begin{array}{c}\text { Terrorist attack } \\
\text { Coup d'Etat }\end{array}$ \\
\hline Slow-onset & $\begin{array}{c}\text { Famine } \\
\text { Drought }\end{array}$ & $\begin{array}{c}\text { Political crisis } \\
\text { Refugee crisis }\end{array}$ \\
\hline
\end{tabular}

Source: Van Wassenhove (2006).

The (immediate) response phase is focused on saving lives and preventing further damage, its aim is to provide immediate assistance to maintain life, improve health and support the morale of the affected population (Eriksson 2009). Disaster relief operations often have to be carried out in an environment with destabilized infrastructure, caused by sudden-onset disasters. The relief is related to the provision of emergency food, shelter and service in the immediate response to a natural disaster (Thomas, Kopczak 2005). Responding to a sudden-onset disaster requires an agile supply chain, thus focusing on effectiveness and rapid response, requiring extensive coordination among all parties instead of cost efficiencies (Kováçs, Spens 2009; Akthar et al. 2012; Rutner et al. 2012). 
In the recovery phase the focus shifts from speed to cost reduction, with an objective being "cost saved means more lives helped" (Cozzolino et al. 2012: 21). Efficiency in the supply chain is the main objective in this phase. However, it is not always clear in which emergency phase a disaster organizations is operating. Each organization may assess things differently so there may be genuine disagreements about priorities. The appropriate transition between the different phases and the mobilisation and disbanding of resources are critical in making the relief effort a success.

Many stakeholders are involved in (humanitarian) disaster relief operations. These include large numbers of uncoordinated and disparate donors, the media, governments, military organizations, (humanitarian) relief and aid organizations and the affected people (Figure 1). There can be as many as several hundred (humanitarian) disaster relief organizations at the scene of a disaster (Van Wassenhove 2006). This makes the coordination during the different phases of the disaster relief operation a considerable challenge.

\section{Figure 1. Actors in disaster relief operations}

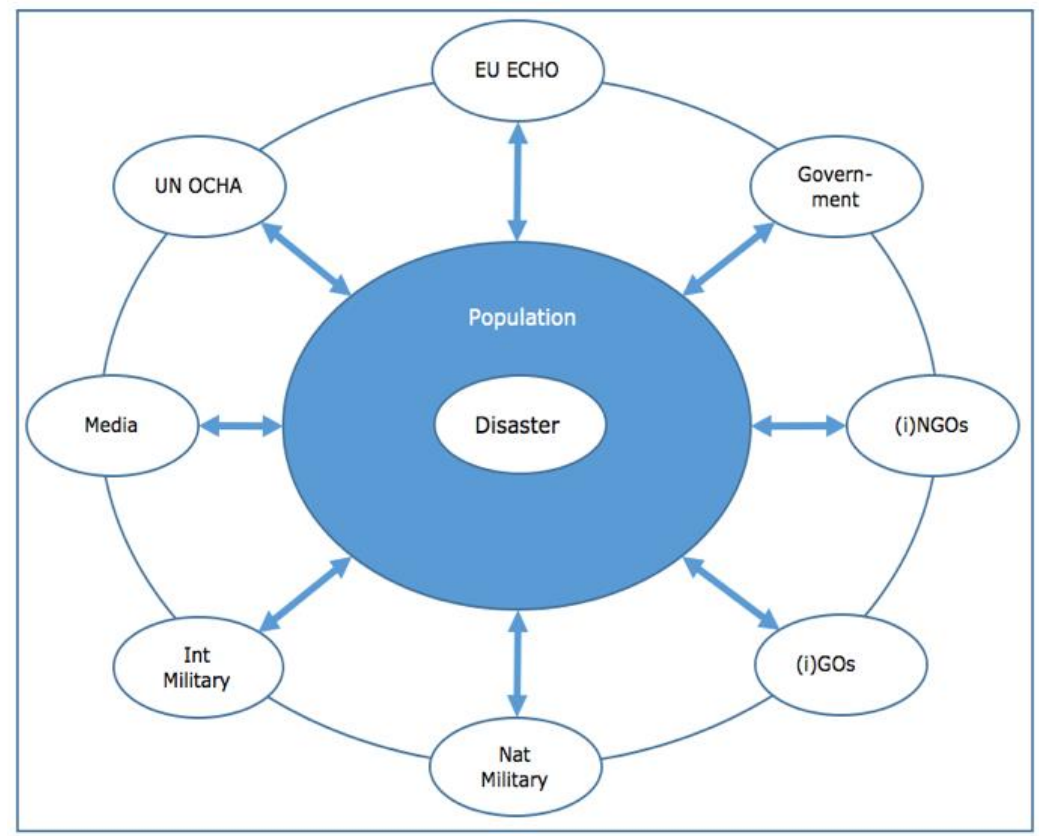

Source: Authors' own elaboration. 
Our focus is on the coordination between military and non-military relief organizations. The non-military relief organizations are all the other actors besides the military organizations, such as the (international) governmental organizations ((i)GOs), the (international) non-governmental organizations ((i)NGOs), the media and last but not least the affected population. Coordination covers all possible forms of inter-organizational interaction that are rooted in common intentions and lead, via negotiation, to agreements whereby the partners are and remain legally, and with certain restrictions, economically independent (Woratschek, Roth 2005).

\subsection{Coordination between military and non-military organizations}

The clear need for inter-organizational coordination within disaster relief operations led to the establishment of topical clusters. The concept of coordination in humanitarian logistics through clusters proposed by Jahre and Jensen (2010) is an approach to minimize the consequences of a natural disaster. In this cluster concept, vertical and horizontal coordination are integrated. The cluster concept involves organizing (humanitarian) help based on a number of sectors with a predefined management. Clusters were introduced to improve the effectiveness of the Office for the Coordination of Humanitarian Affairs (OCHA) in the five following key areas:

- Satisfactory global capacity to react to current and future crisis

- Trustworthy and predictable leadership at a global and local level

- Unbreakable alliances between UN bodies, (i)NGOs and (local) authorities

- Responsibility, both for the reaction and in relation to receivers

- Strategic field-level organization and prioritization.

Three main aspects are essential for the cluster system: selected global direction, central and local competence construction and suppliers of last alternative.

The cluster concept is based on a global perspective and then customized for a particular location while the event occurs. Each global cluster is constant, permanent and directed by one assigned group. As one cluster is permanent and organized from a global perspective, it offers a large flexibility in its response to the incident.

The global management of the clusters has a special task of creating both central and local competence. The global cluster management has a vital role in creating 


\section{SAVING LIVES WITH FEWER DISCUSSIONS}

competence on a global level and the coordination between different small or large areas of assistance.

The supplier of last alternative is another important part of the cluster system. According to this concept, the last alternative provider commits to supplying any necessary service, when all other organizations are not able to. It is a large responsibility because, the last alternative provider takes on a leading position with timeless commitments, without the resources to meet them.

The basics for complex disaster relief coordination are the elements communicate, coordinate and information sharing. The different stakeholders have different understandings of these elements (Bjerge et al. 2016). These elements are the main activities for the cluster system. There is danger that coordination will be focused on within-cluster coordination, and primarily at the operational level with some efforts at the strategic level through the global cluster lead (Jahre, Jensen 2010).

Coordination during disaster relief operations can be found at three levels: operational, tactical and strategic. These levels are important for any disaster relief operation because it has been proved to be inefficient to centralise operations completely at the global level, and because regional organizations and transportation are necessary when global supply chains are too slow (Schulz, Heigh 2009). The lack of coordination among (humanitarian) relief organizations is seen as a big challenge (Kaba 2007; Osei-Akom 2007), especially on strategic and tactical level. Coordination on the operational level between military and non-military relief organizations seems to be more common (Jahre, Jensen 2010; Listou 2011; Rutner et al. 2012; Jensen, Hertz 2016). During (humanitarian) relief operations, strongly motivated people in both civil and military camps usually find ways to surmount barriers that they encounter, but valuable time is lost inventing and reinventing these solutions (Heaslip, Barber 2014).

Coordination can be hampered by a lack of knowledge about each other (e.g. Kaba 2007; Osei-Akom 2007). Humanitarian relief organizations live by their principles of humanity, neutrality and impartiality. In other words, they will help everybody in need wherever found; will not influence the outcome of a conflict with their intervention; and will not favour one group of beneficiaries over another. These 
principles define the 'space' (Figure 2), both physically and virtually, in which they need to be able to operate to do their job effectively (Van Wassenhove, 2006).

\section{Figure 2. 'Humanitarian space'}

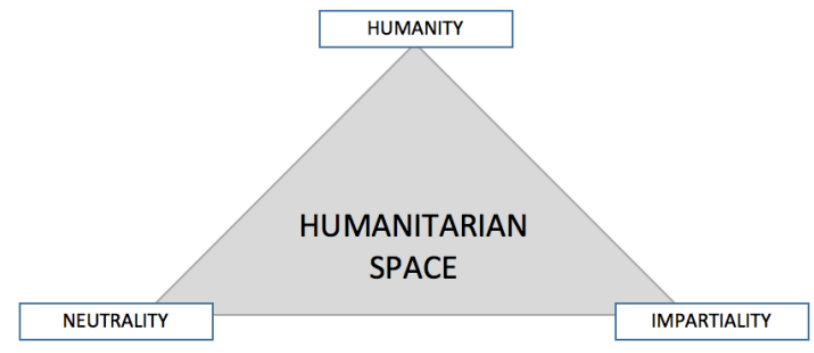

Source: Van Wassenhove (2006).

One of the main challenges for coordination between military and non-military organizations lies in the mutual respect of the organizational and culture differences (Schulz, Blecken 2010; Rietjens et al. 2007; Balcik et al. 2010; Heaslip et al. 2012). So, how can relief organizations overcome the disconnect in mutual understanding on strategic and tactical levels?

\subsection{The role of military organizations}

The Oslo Guidelines, which originated in 1992 and were updated in 2006, are guidelines on the use of foreign military and civil defence assets in disaster relief. The aim of the Oslo Guidelines is to establish the basic framework for formalizing and improving the effectiveness and efficiency of foreign military and civil defence assets in IDRA.

For the purpose of the Oslo Guidelines assistance can be divided into three categories based on the degree of contact with the affected population.

- Direct assistance: the face-to-face distribution of goods and services

- Indirect assistance: at least one step removed from the population and involves such activities as transporting relief goods or relief personnel

- Infrastructure support: general services, such as road repair, airspace management and power generation that facilitates relief, but not necessarily visible to or solely for the benefit of the affected population. 
The Oslo Guidelines state that humanitarian assistance (and in non-conflict disaster also International Disaster Relief Assistance (IDRA)) must be provided in accordance with the humanitarian principles: humanity, neutrality and impartiality. Military assets should be seen as a tool complementing existing relief mechanisms to provide specific support for specific requirements, in response to the acknowledged "humanitarian gap", or as a last resort (OCHA 2007).

Despite humanitarian perceptions of effective coordination, the humanitarian community is not very familiar with the Oslo Guidelines. Bollettino (2014) concluded that only $12 \%$ of the respondents thought that the Oslo Guidelines were used to develop organizational policy on humanitarian aid agency engagement with military actors. Even when the Oslo Guidelines are known, they can lead to a different view on the principles of fulfilling the 'humanitarian gap'. With this knowledge, the following research question is relevant: to what extent does the unfamiliarity with the Oslo Guidelines to unnecessary discussions and delay between military and non-military relief organizations?

Jensen and Hertz (2016) identified three main role categories in providing humanitarian assistance:

- Specialist provider: clear role recognised by all with very specialised competences

- Broad provider: recognised organization with substantial resources, but not very specialised

- Generalist: competences are not very specialised, limited resources.

This concept of roles can be seen as a first level of organising the (humanitarian) relief supply chain, thus avoiding some of the basic need for coordination when time is most pressing (Jensen, Hertz 2016), but how fits the military assistance within these roles?

In the international humanitarian community, there are different opinions on the role of the military organization during disaster relief operations. Military forces often play an important role in providing support during a disaster due to their strength in logistical and organizational structure (Apte 2009; Barber 2011; Heaslip 2011; Heaslip et al. 2012). The ability to quickly establish presence in the disaster 
zone whilst delivering large volumes of relief in the hours and days following a disaster helps to reduce the "gap of pain" that has been described as the time between the demand for aid and the time in which the aid is provided (Rietjens et al. 2008; Barber 2010; Heaslip 2011). This is why Thompson (2010) and Tatham and Rietjens (2016) state that the military organization has a specific role in the assistance in support of logistic activities in the (immediate) response phase.

Barber (2012) identified more roles and tasks for the military organization in disaster relief operations in the (immediate) response phase, especially for military logisticians. The military logisticians can provide security, open transport and storage facilities, command and control distribution within and into disaster areas, restore communication systems, provide protection for incoming aid, assist with urgent air lifts and drops of aid in inaccessible locations and re-establish basic infrastructure.

The views on the role of military organizations during disaster relief operations differ from specialist (Thompson 2010; Tatham, Rietjens 2016) to broad provider (Jensen, Hertz 2016) and in delivering direct, indirect assistance and even infrastructure support (Oslo Guidelines, 2006). With the 'humanitarian principles' in mind, the following research question can be further investigated: is the actual role of military organizations limited to a broad provider role and delivering indirect assistance in the (immediate) response phase during disaster relief operations?

\section{Methodology}

We adopted a case study approach to gain insights in the coordination problems between military and non-military organizations. A case study is typically well suited for an explorative study that intends to investigate coordination problems at operational, tactical, and strategic levels in the (immediate) response phase of a disaster relief operation (Yin 2013). We examined the support of the Dutch military organization and its coordination with the non-military organizations after hurricane Matthew on Haiti in October 2016. The selection of the case was based on the consideration that we aim to investigate a sudden-onset disaster with a completed 
After Action Review of OCHA, where different military and non-military relief organizations were present and active.

The study included analysis of relevant documents and interviewing key respondents. Information was obtained from semi-structured interviews, journals, and relevant documents. The documents, which are used for this case study, are the After Action Review (AAR) of the disaster relief operation of hurricane Matthew from OCHA, the flash appeals (OCHA and European Commission's Humanitarian Aid and Civil Protection Organization (ECHO)) and the situation updates from the Logistic Working Group. In addition, we analysed the coordination forums on the different organizational levels that provide insights in the communication lines and coordination problems between military and non-military organizations.

Respondents were selected from the Dutch military forces (Ministry of Defence (MoD)), the Ministry of Foreign Affairs (MoFA), the UN OCHA, UNDAC, EU ECHO and INGOs (International Federation of the Red Cross, OXFAM NOVIB and CORDAID). A total number of 12 interviews were conducted with respondents, covering the three organizational levels (strategic, tactical, and operational). The key-informants can be divided in several categories. First, they can be divided in military (five persons) and non-military disaster relief organizations (seven persons). Second, they can be divided in the different organization levels; strategic level (four persons), tactical level (seven persons) and operational level (four persons). The sum of these representatives is above twelve, but the reason for that is that some of the representatives were active on different organizational levels during the disaster relief operation of Matthew. The answers of the representatives are also crosschecked to obtain an objective view on the different propositions.

The interview guidance is based on the questionnaire that is used for the report by the Stockholm International Peace Research Institute (SIPRI) on effectiveness of foreign military assets in natural disaster response (SIPRI 2007). The questions are based on the six (interconnected) aspects of effectiveness (cf. Van Schoorl 2010).

Besides the fact that the questions for the interviews are based on a validated interview guidance, the interview questions are also validated with other peer researchers to make sure that the questions deliver the answers needed for this case study and that the interviews are representative for this research. An interview 
typically lasted 60-90 minutes. All interviews were recorded and transcribed. For reasons of validity, we provided respondents the opportunity to check and recheck interim reports

This case not only focusses on the coordination between the different organizations, but also on different organizational levels (strategic, tactical and operational level). During the disaster relief operation of hurricane Matthew, the Dutch military organization supported Haiti and the international relief operation by sending two Dutch Royal Navy ships. These ships delivered logistics (transport capacity and relief goods) support, security and infrastructure repair capacity. The non-military relief organizations in scope of this case are CORDAID, Oxfam Novib, the International Federation of the Red Cross (IFRC), the UN OCHA, the EU ECHO and the Dutch Ministry of Foreign Affairs.

\section{Results case study hurricane Matthew}

\subsection{Disaster relief for hurricane Matthew}

Hurricane Matthew was a powerful Atlantic hurricane, category 4 on the SaffirSimpson scale that made landfall on the 4th of October in 2016. Hurricane Matthew cost more than a thousand lives on Haiti and more than 1.4 million people required immediate assistance. The OCHA released a Haiti Flash Appeal of \$119.9 million on the 10th of October (updated on the 19th of October), which was required to provide 750000 people with life-saving assistance and protection in the next three months.

The disaster relief operation started before hurricane Matthew made landfall. An UNDAC team was sent to Haiti to make an assessment. Directly after the disaster, the government of Haiti was in a state of chaos, so it took a while for the Government of Haiti officially requested assistance of the international community. The UN OCHA decided to increase the UNDAC capacity with an extra team and ECHO sent a Civil Protection Team (CPT) for coordination. Because the Government of Haiti wanted to stay in charge, they did not want the 'cluster system'. Instead of the 'cluster system', they set up the 'Sector system'. The advisor 
of the sector logistics was the World Food Program (WFP) (within the UN Cluster system the leading organization for the logistic cluster).

\section{Figure 3. Hurricane Matthew on Haiti}

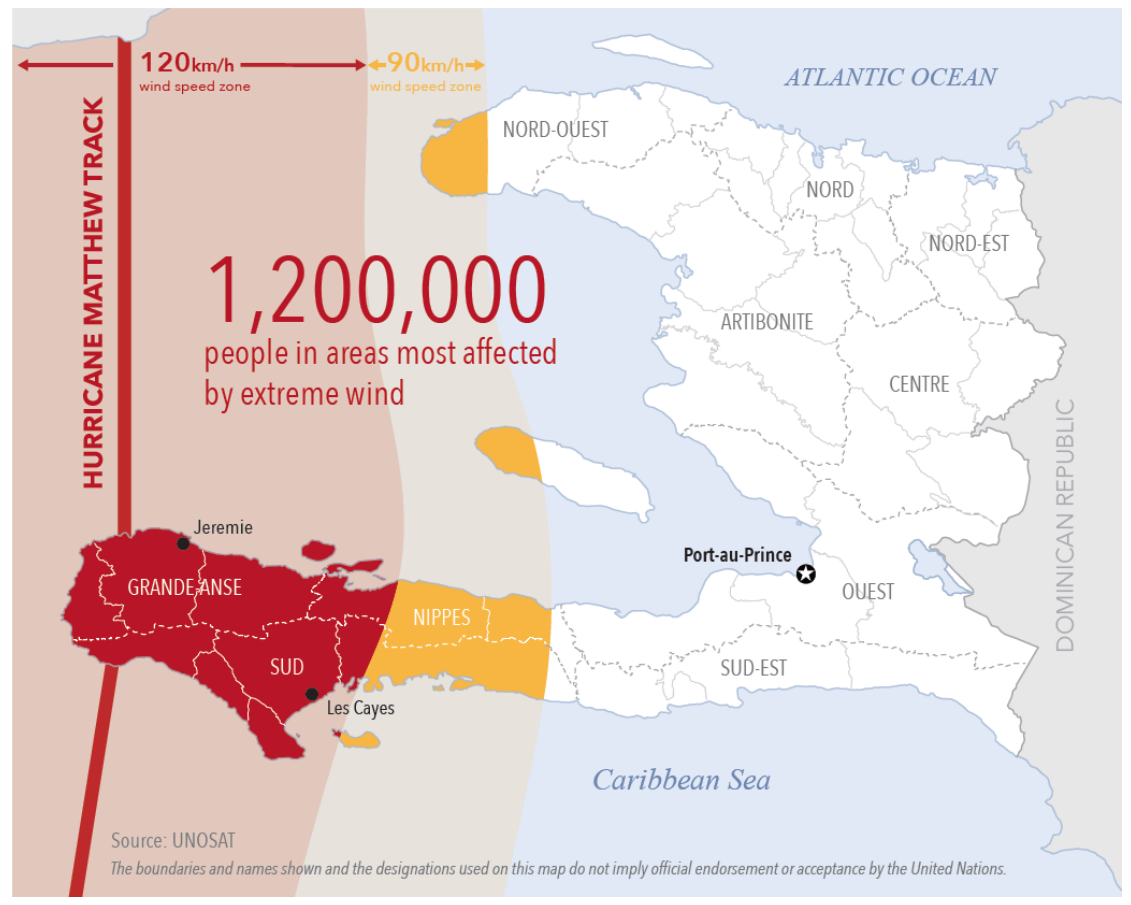

EU ECHO received a request for support from OCHA. The EU released $€ 3.755$ million (ECHO Factsheet Haiti, 17 November 2016) to fund emergency humanitarian assistance. Some members offered also relief capacity for the disaster relief operation on Haiti. Late in the evening of the 4th of October, the Netherlands received the request for support. This request had to be staffed by the Dutch government. On the 7th of October, the MoFA and the MoD agreed to support for the relief operation in Haiti and they offered two Navy ships with transport capacity, force protection and reconstruction capacity.

For legal reasons, there had to be bilateral arrangement between Haiti and the Netherlands. The MoD insisted in arming the Dutch military personnel for their own protection. This led to a discussion with MoFA. After a few days, it was decided that 
the military organization would support the disaster relief operation with armed personnel.

The decision about the armed personnel and other arrangements (declarations of goods, etc.) had to be in a 'Note Verbale'. It took several days before the 'Note Verbale' was signed by Haiti, because they were not familiar with the correct procedures. In the meantime, the two Navy ships moved to Haiti. But the personnel were not allowed to enter Haiti before the 'Note Verbale' was signed. This delay frustrated the personnel on the ships, because they wanted to help people. It also frustrated the local authorities and the non-military relief organizations, because they needed the support of the ships and personnel. The Dutch commanders used the time to coordinate and explain the problems to the local authorities, representatives of the non-military relief organizations and the media on board of their ships. On the 11th of October, the 'Note Verbale' was signed and the two Navy ships could start with their relief support.

The two Navy ships provided transport of goods for non-military relief organizations to locations that were not accessible by road. Dutch engineers also supported with restoring roads and repairing a hospital. The Dutch military also examined the coastline for safe places to moor. For the coordination of the 'last mile' distribution, the ships had representatives of the local authority and representatives of the non-military relief organizations on board. Before the actual distribution, these representatives were in contact with their colleagues on shore to organize the delivery of these goods. The whole process was orderly, because of the coordination in advance and the support of the military personnel. There were no weapon incidents with Dutch armed military during the support of the relief operation.

The Netherlands offered support with two ships for one week. At the end of that week, the Netherlands received a request for another week via the official channels of the EU and UN. The Netherlands complied with this request. There was a second request for prolongation of the two ships after the second week. This request was not granted by the Netherlands and for that reason the support came to an end on the 26th of October. This led to a problem in the transport capacity during the relief 
operation. The contract for civil transport capacity to take over the role of the Dutch ships was not yet in place.

\section{Figure 4. Timeline for the Dutch military relief operation}

\begin{tabular}{|c|c|c|c|c|}
\hline $\begin{array}{c}4 / 10 / 2016 \\
\text { Start preparation } \\
\text { for support }\end{array}$ & $\begin{array}{c}\text { 7/10/2016 } \\
\text { Request } \\
\text { accepted }\end{array}$ & $\begin{array}{l}11 / 10 / 2016 \\
\text { Start relief } \\
\text { operation }\end{array}$ & $\begin{array}{c}\text { 16/10/2016 } \\
\text { Request } \\
\text { accepted }\end{array}$ & $\begin{array}{l}26 / 10 / 2016 \\
\text { End of relief } \\
\text { opperation }\end{array}$ \\
\hline $\begin{array}{l}\text { 4/10/2016 } \\
\text { Hurricane Matthew } \\
\text { made landfall on Haiti }\end{array}$ & $\begin{array}{l}\text { 4/10/2016 } \\
\text { Request for } \\
\text { support }\end{array}$ & $\begin{array}{l}11 / 10 / 2016 \\
\text { 'Note Verbale' } \\
\text { signed }\end{array}$ & $\begin{array}{l}16 / 10 / 2016 \\
\text { Request for } \\
\text { prolongation }\end{array}$ & $\begin{array}{l}26 / 10 / 2016 \\
\text { Request for } 2 \text { nd } \\
\text { prolongation }\end{array}$ \\
\hline
\end{tabular}

Source: Authors' own elaboration

\subsection{Coordination on different organizational levels}

The first request for help was between Haiti and the Netherlands on strategic level. Figure 5 shows the official request for help procedure. The procedure of the request for prolongation is the same. On tactical level, the logistic support was coordinated by the Logistic Working Group (LWG) from the WFP. The LWG daily organized logistic meetings. Over 50 military and non-military relief organizations were attending these meetings. The Dutch military organization sent a Liaison Officer (LO) to attend these LWG meetings. After the arrival of the two Dutch ships in the territorial waters of Haiti, the LO coordinated their support for the relief operation during the LWG meetings, on tactical (regional) level (Figure 6).

The commanders invited the representatives of the supported non-military relief organizations and the local authorities on board to coordinate on the operational level (Figure 7). These representatives were in contact with their local counterparts, where the people in need were. 
Figure 5. Request coordination

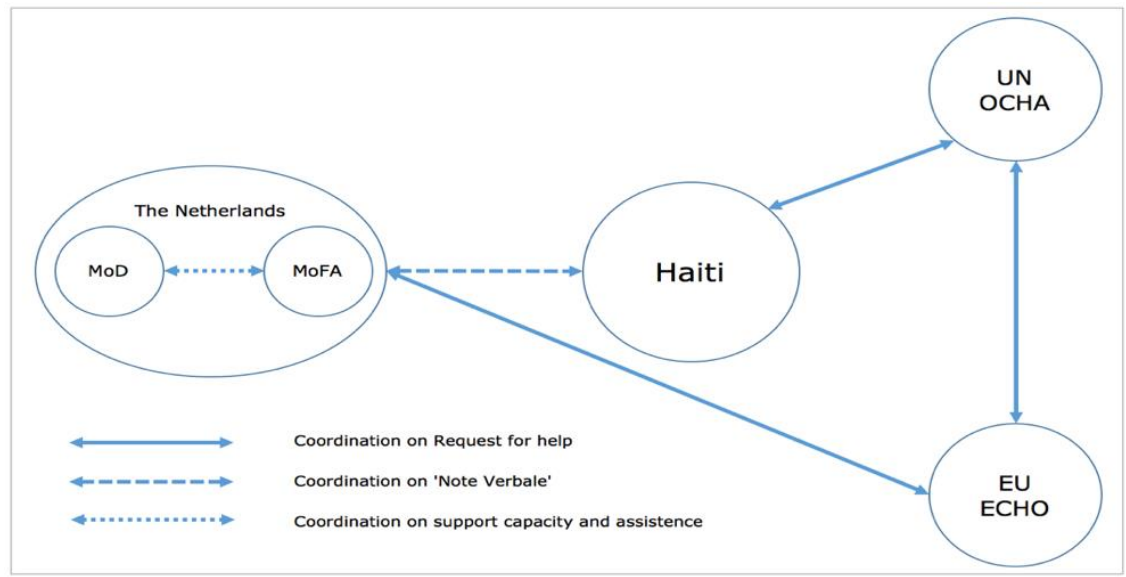

Source: Authors' own elaboration

\section{Figure 6. Coordination on tactical level}

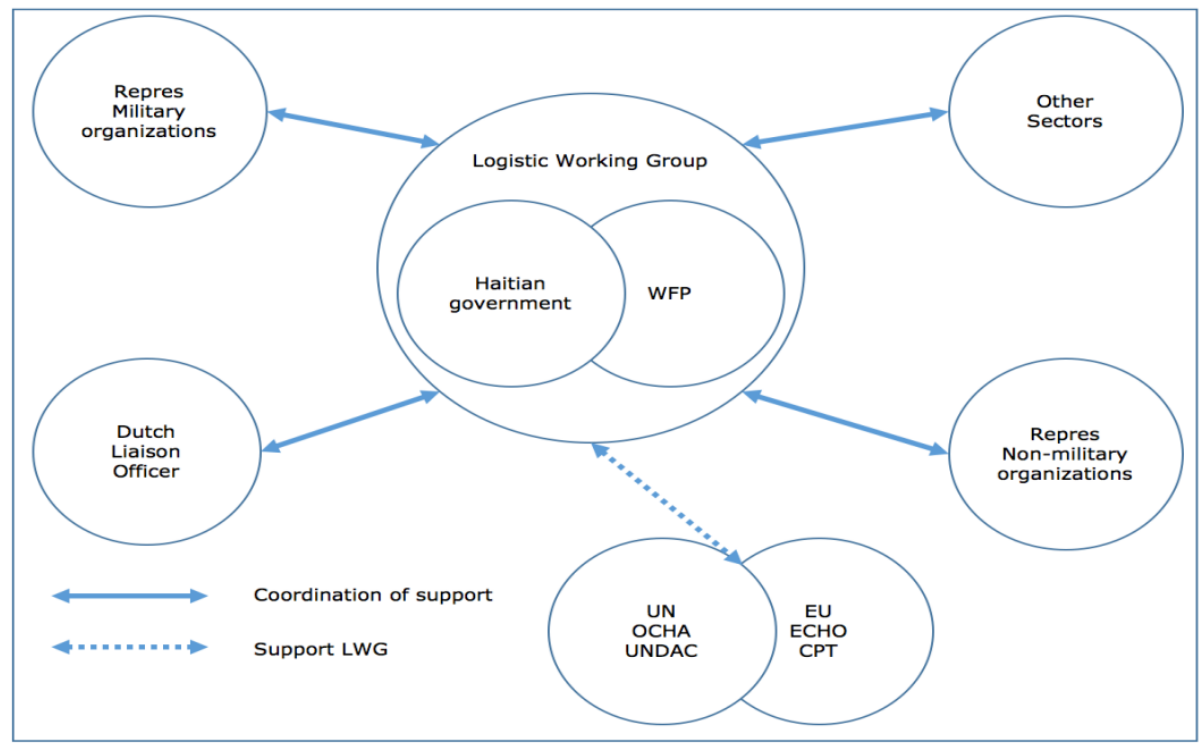

Source: Authors' own elaboration 
Figure 7. Coordination on operational level

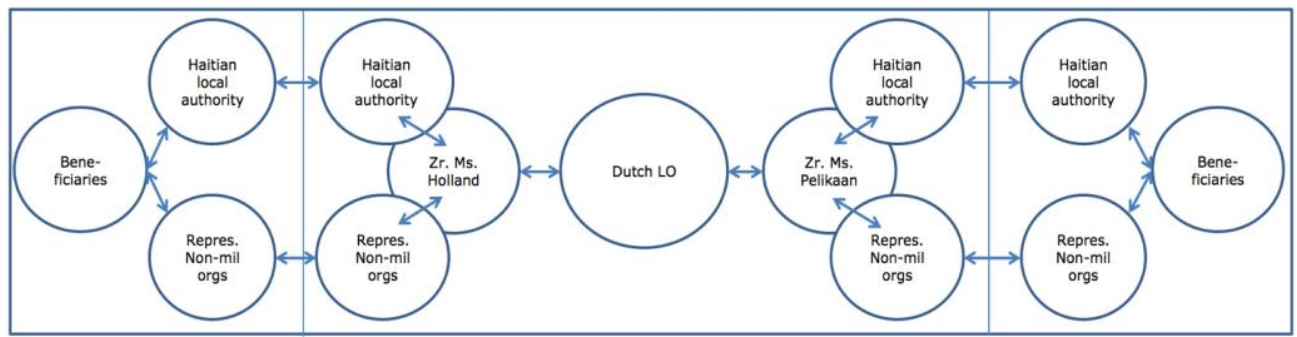

Source: Authors' own elaboration

Figure 8 shows the military chain of command during the disaster relief operation of Matthew. The commander of the Zr. Ms. Holland was the highest in rank on location. After a few days, the Dutch military organization experienced that the official chain of command was too complex during the disaster relief operation. The Dutch LO was acting on operational level in the national chain of command and at the same time he was the point of contact on tactical level for the disaster relief. The official chain in command stayed intact, but it was up to the Dutch LO to coordinate with the Defence Staff.

Figure 8. Military chain of command during hurricane Matthew

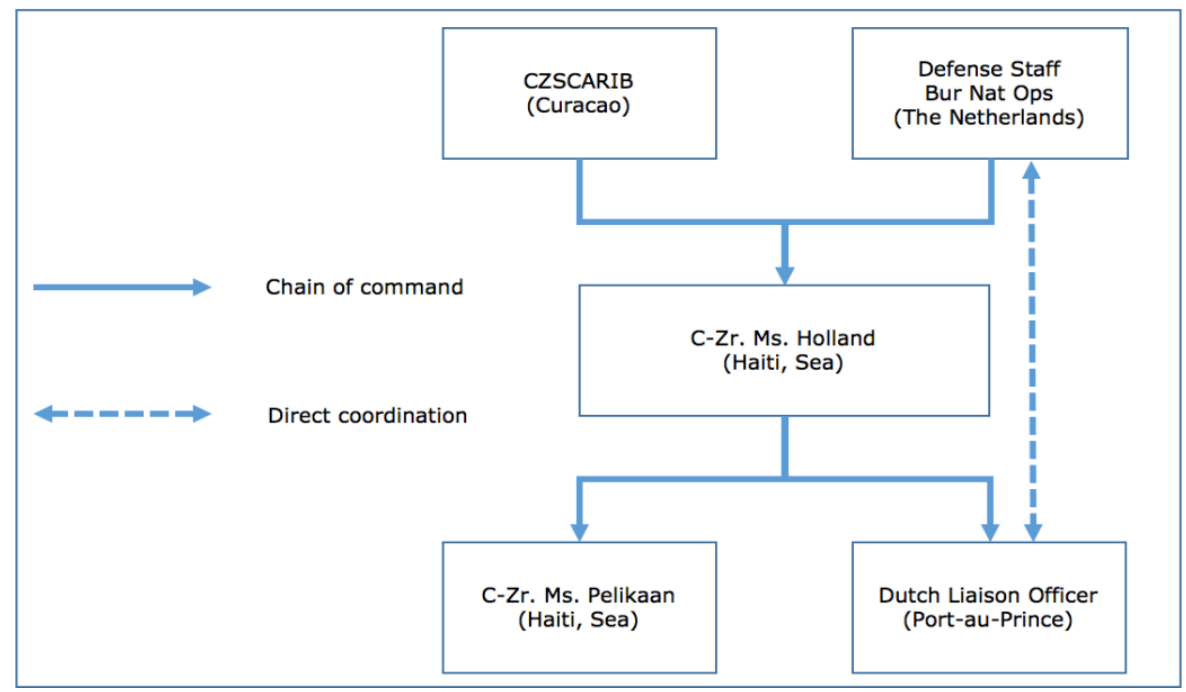

Source: Authors' own elaboration 


\subsection{Coordination between military and non-military organizations}

The coordination between military and non-military organizations on the operational level seemed to be no problem. Throughout the execution of the relief operations, no cultural of organizational problems hampered the coordination between both organizations. Menno van der Eerden (Commander of Zr. Ms. Holland, interview): "The coordination went well. In the beginning, we had to learn to know each other. But after a while we knew the roles of the different organizations". Frank Jonker (Commander of the engineer group, interview): "There wasn't even an language barrier". All the respondents on the operational level answered that the coordination between the military and non-military organizations was effective.

The coordination challenges and problems between military and non-military relief organizations have been experienced on the strategic and tactical level. The non-military relief organizations experienced problems with the 'humanitarian space'. Fanny de Swarte (EU ECHO, interview): "A lot of non-military relief organizations depend on the goodwill of the parties involved. Being perceived as a neutral party is essential for non-military relief organizations. There are moments your life depends on being seen as neutral".

The coordination challenges and problems on strategic level occurred between the Ministry of Foreign Affairs and the Ministry of Defence. That had to do with the familiarity with the Oslo Guidelines.

\subsection{The Oslo Guidelines}

The Oslo Guidelines gives guidance on the use of foreign military and civil defence assets in disaster relief. However, in practice the Oslo Guidelines are not known and/or not used. Only seven of the twelve respondents (the answers from the MoFA consists of two respondents) are familiar with the Oslo Guidelines. Two respondents of the military organizations are familiar with these guidelines. Apparently, there is not much attention for these guidelines in the military organization in preparation of the support during the disaster relief operation. 


\section{SAVING LIVES WITH FEWER DISCUSSIONS}

Two respondents answered that the Oslo Guidelines were leading in the coordination between the military and the non-military relief organizations. That means that $17 \%$ of the respondents used the guidelines to coordinate. Even the most non-military relief organization do not use these guidelines for coordination with military organizations.

Ronald Christiaans: "The Guidelines are not leading for us. We just ask for what we want and the military organization decides whether they can facilitate or not" (UN UNDAC, interview annex 7.7). Fanny de Swarte: "Yes, on strategic and tactical level we applied these guidelines. On operational level, it is pragmatically" (EU ECHO, interview).

On strategic level, the Oslo Guidelines led to discussions regarding weapons. The military organization consisted in supporting the disaster relief operation with armed personnel. The lessons learned from other disaster relief operations, such as the earthquake on Haiti or the cyclone on Dominica: "handling aid goods and ensuring that they find their way to their proper destination can only take place in a secure and secured environment" (Houben 2009). The respondents from the MoFA wanted that the 'Humanitarian space' was ensured. That mend in their opinion that the military organization was not allowed to carry any weapons during the operation. They based their opinion on the Oslo Guidelines. The legal advisors of the Ministry of Defence concluded that this was not an issue in the Oslo Guidelines. After several days of discussion, the decision was made that the military organization was allowed to support the disaster relief operation with armed personnel.

Ministry of Foreign Affairs (interview): "To come into action, there had to be a signed 'Note Verbale'. We had the content of this letter, but the Ministry of Defence wanted the condition that they could operate with armed personnel during the emergency relief operation because of their experience during the earthquake on Haiti in 2010. This had to be included in the 'Note Verbale' and that took a while." Stefan Maureau (MoD, interview): "Gladly, we hold on to our demand to send our troops armed with weapons. In Haiti, convoys were ambushed, but that did not happen to the Dutch military organization". 
In case of the disaster relief operation of Matthew it seems that armed personnel played a decisive role in the support. It prevented chaotic situations and looting.

\subsection{The role of the military relief organization}

The Dutch military organization supported the transport capacity, force protection, engineering capacity for reconstruction of infrastructure and capacity for measurements of the depth of the quays. The support was very much appreciated. Stefan Maureau (MoD, interview): "The provided help was very good and we received compliments from Haiti and the UN. This is a sign that the emergency relief was good".

Generally, the military organization is willing to take part in relief operations. Their capacity and speed of action can be very helpful for the immediate response to a disaster. But the government decides if the military organization takes part in the disaster relief operation when requested. Stefan Maureau (MoD, interview): "We only fulfil the requested emergency relief support. The requesting country asks for what they need. We can or cannot meet the request and the governments decides if we are going to support the request". Fanny de Swarte (EU ECHO) was very clear on the question about the role of the military organization: "Preferably as little as possible". Her reaction has to do with the attitude and behaviour of the military organizations. The Dutch military organization was very cooperative during the disaster relief operation of Matthew, but normally military organizations want to take the lead in disaster relief organizations and they are not as efficient as they think they are. The fact that being perceived as a neutral party is essential for nonmilitary relief organizations. Coordination with military organization could endanger this neutrality and with that the personnel of the non-military relief organization (Fanny de Swarte EU ECHO).

The main opinion of the respondents is that the military organization is a last resort and only during natural sudden-onset disasters whithout conflicts. This is in line with the Oslo Guidelines. Annick van Lookeren Campagne of Oxfam Novib (interview): "My opinion is that the military organization is a last resort. In case of a natural disaster, the role of the military organization is less political. However, in 
case of conflicts, the military organization is not the desired relief organization to act within the humanitarian principles".

Just as Stephen MacAndrew stated: "They can provide some support, such as heavy lift or logistics support, but they are not humanitarians" (IFRC, interview).

\section{Conclusions and discussion}

Coordination between military and non-military relief organizations during disaster relief operations takes place on different organizational levels. The literature showed that coordination at operational level is more common than at tactical and strategic level. The case study showed the same phenomenon. At operational level, the military and non-military relief organizations had no problems with the coordination. At tactical and strategic level, they indeed experienced challenges and problems with the coordination.

\subsection{The disconnect in mutual understanding}

On operational level, both military and non-military relief organizations focusses on the main goal, saving lives and overcoming the (coordination) problems. Strongly motivated people in both camps (i.e. civil and military) usually find ways to surmount barriers that they encounter (Heaslip, Barber 2014). The relief workers see what a disaster really leads to and are confronted with the losses of lives.

On tactical, but certainly on strategic level, the distance between the people in need and the relief organizations can lead to another perception of urgency. The difference in understanding between the military and non-military organizations is larger on tactical and strategic level than on operational level. 'Ignorance breeds contempt'.

On tactical level, coordination challenges and problems occurred between military and non-military relief organizations. These problems occurred mainly on cultural aspects. Stephan MacAndrew of the IFRC illustrated the disconnect in mutual understanding very clear, when he said that the military are very helpful, but not humanitarian. 
Coordination challenges and problems on strategic level are mostly related to the 'humanitarian space' of the relief organizations. The participation of military organizations lead to challenges and problems with neutrality, humanity and impartiality. This became clear with the coordination between the Dutch MoFA and MoD. For the MoFA, the 'humanitarian space' meant no armed personnel, which they substantiated with the 'Oslo Guidelines'. Legal experts of the Dutch MoD pointed out that the Oslo Guideline does not prohibit armed personnel for selfprotection of self-defence.

\subsection{The unfamiliarity with the Oslo Guidelines}

Vincenzo Bollettino (2014) concluded in his study on the Oslo Guidelines that only $12 \%$ of the respondents of his survey (a skilled group of professionals with many years of professional experience) thought that the Oslo Guidelines were used to develop organizational policy on humanitarian aid agency engagement with military actors. This case study showed the same trend. Only six of the twelve respondents are familiar with the Oslo Guidelines and only two key-informants said that these guidelines were leading for their organizations to coordinate with other organizations.

The unfamiliarity and lack of clarity of the Oslo Guidelines led to the discussion between the Dutch MoFA and MoD. This discussion cost a lot of precious time to overcome this difference. This result leads to discussions on what to do with the Oslo Guidelines. In the OCHA community, all the participants agreed upon the Oslo Guidelines. However, the aim of the guidelines, establish the basic framework for formalizing and improving the effectiveness and efficiency of the use of foreign military and civil defence assets in international disaster relief operations, is not reached.

\subsection{The role of the military organization in relief operations}

The opinion of the humanitarian community is that military organizations are not humanitarian organizations. So, there is no role for military organizations within (humanitarian) disaster relief operations. On the other hand, military organizations have a lot of transport and other useful capacities. They can deploy very fast and at 


\section{SAVING LIVES WITH FEWER DISCUSSIONS}

(almost) every place where non-military relief organizations cannot come. With these characteristics, the military organization can be very helpful during disaster relief operations. The role of broad provider with direct and indirect assistance fits well. Tatham and Rietjens (2016) only see an indirect assistance role with logistic support for the military organization. Non-military relief organizations requires that the military organizations only have a role during natural sudden-onset disaster relief operations in non-conflict areas. Then it is (or can be) safe for the humanitarian worker to coordinate and work with the military organizations.

The opinions within the military community also vary. Some of the military key-informants are convinced that the military organization has to wait for official requests for support while other military key-informants are convinced that the military organization has to be prepared for possible disasters in areas where there is a higher possibility of the occurrence of disasters. The variety of opinions is also found in the literature. The main opinion is that military organizations has a specialist and broad provider role in disaster relief operations, because they can rapidly deploy with various useful material for disaster relief operation for direct and indirect assistance. Especially in the supply chain of disaster relief operations.

For the coordination between the military and non-military relief organization it is essential that the roles of the organizations are clear. There are several aspects that the military and non-military relief organizations agree upon. First of all, the organizations see the importance of a broad provider logistic indirect assistance role for the military organization, especially with transport capacity. Secondly, the construction capacity of the military organizations can be used in the (immediate) response phase when there is no other possibility to reconstruct the infrastructure. And third, the military organizations have to hand over the relief goods for 'the last mile delivery' to the local non-military relief organizations.

\section{Recommendations}

The results of this study can be used to provide recommendations for practice. How can the coordination between the military organization and the non-military 
relief organization during disaster relief operations be improved? Our study suggests that the common and mutual respect and a clear task and role fulfilment are critical for coordination between military and non-military relief organizations. On tactical and strategic level, the lack of mutual understanding on the organizational and cultural differences between military and non-military relief organizations is likely to result in challenges and problems with the coordination. Unfamiliarity with the different organizations can contribute to a lack of common and mutual respect of the cultural and organization values.

The military organizations do not have clearly defined tasks and roles within the disaster relief operations. The guidelines for the tasks and roles as stated in the 1994 Oslo Guidelines are not actually used by organizations within disaster relief operations. Even during natural made sudden-onset disasters without a conflict, there is no consensus on the role of the military organization. To improve the coordination between the military and the non-military relief organizations, there must be paid more attention to get mutual understanding on tactical and strategic level. In addition, the military organizations must have a clear role during disaster relief organizations. A first step to improve the coordination is to get familiarity and clarity on the Oslo Guidelines. Another step for improvement is for the military organization to accept that it has no leading but an assistance role during disaster relief operations. The difficulty for a clear task and role fulfilment, is that the military organization can have a direct or indirect assistance role. The military has an indirect assistance role, but dependent on the circumstances it has to fulfil a direct assistance and/or an infrastructure support role. The focus has to be on coordination before the concerning disaster relief operation to clarify the role of the military organizations.

We recommend a discussion about the familiarity and the goal of the Oslo Guidelines. Are these Oslo Guidelines still valid, should they be updated or thrown away? And when the guidelines are still valid, the content has to be familiar with all the participating organizations. To get the organizations familiar with the Oslo Guidelines and the other relief organizations, OCHA has to make the education programs, courses and trainings mandatory before participating in the cluster system during disaster relief operations. 
Future research could be to conduct a comparable case study with military organizations other than the Dutch military. To get more details on the coordination challenges and problems, research can focus on the possible differences between the coordination between military organizations and (i)GOs and coordination between military organizations and (i)NGOs.

\section{References}

Ahmadi M., Seifi A., Tootooni B. (2015), A humanitarian logistics model for disaster relief operation considering network failure and standard relief time. A case study on San Francisco district, „Transportation Research Part E: Logistics and Transportation Review”, vol. 75, pp. 145-163.

Allied Administrative Publications (AAP) 06 (2013), NATO Glossary of Terms and Definitions, https://www.academia.edu/10269177/AAP-6_NATO_Glossary_of_Terms_and_Definitions_2013 [31.05.2019].

Altay N., Green W.G. (2006), OR/MS research in disaster operations management, ,European Journal of Operational Research", vol. 175 no. 1, pp. 475-493.

Altay N., Labonte M. (2014), Challenges in humanitarian information management and exchange. Evidence from Haiti, „Disasters”, vol. 38 no. s1, pp. s50-s72.

Apte A. (2009), Humanitarian logistics. A new field of research and action. Foundations and trends in technology, „Information and Operation Management”, vol. 3 no. 1, pp. 1-100.

Balcik B., Beamon B.M., Krejci C.C., Muramatsu K.M., Ramirez M. (2010), Coordination in humanitarian relief chains. Practices, challenges and opportunities, „International Journal of Production Economics", vol. 126 no. 1, pp. 22-34.

Barber E. (2012), Military involvement in humanitarian supply chains, in: Relief supply chain management for disaster. Humanitarian aid and emergency logistics, Kovács G., Spens K. (eds.), IGI Global, Hershey, PA, pp. 123-146.

Bjerge B., Clark N., Fisker P., Raju E. (2016), Technology and information sharing in disaster relief, „PLOS One”, vol. 11 no. 9, pp. 1-20.

Centre for Research on the Epidemiology of Disasters (2016), 2015 disaster in numbers, www.cred.be/publications [31.05.2019].

Cozzolino A., Rossi S., Conforti A. (2012), Agile and lean principles in the humanitarian supply chain. The case of the United Nations World Food Programme, „Journal of Humanitarian Logistics and Supply Chain Management", vol. 2 no. 1, pp. 16-33.

Cross T. (2012), Disaster agencies and military force - not such strange bedfellows after all!, in: Humanitarian logistics. Meeting the challenge of preparing for and responding to disasters, Christopher M., Tatham P. (eds.), Kogan Page, London. 


\section{Johan STEVENS, Janjaap SEMEIJN, Cees J. GELDERMAN}

Day J.M., Melnyk S.A., Larson P.D., Davis E.W., Whybark D.C. (2012), Humanitarian and disaster relief supply chains. A matter of life and death, „Journal of Supply Chain Management”, vol. 48 no. 2, pp. 21-36.

Eriksson E. (2009), Knowledge transfer between preparedness and emergency response. A case study, „Disaster Prevention and Management”, vol. 18, no. 2, pp. 162-169.

Fernandez T.E., Suthikarnnarunal N (2011), The main aims of humanitarian, business and military organizations and the resulting possible synergies in logistics, „Lecture Notes in Engineering and Computer Science”, vol. 2194 no. 1, pp. 1141-1143.

Ganguly K., Rai S.S. (2016), Managing the humanitarian relief chain. The Uttarakhand disaster issues, „Journal of Advances in Management Research”, vol. 13 no. 1, pp. 92-111.

Heaslip G. (2011), Challenges of civil military cooperation/coordination in humanitarian relief, in: Relief supply chain management for disasters. Humanitarian aid and emergency logistics, Kovács G., Spens K. (eds.), IGI Global, Hershey, PA, pp. 147-172.

Heaslip G., Barber E. (2014), Using the military in disaster relief. Systemizing challenges and opportunities, „Journal of Humanitarian Logistics and Supply Chain Management”, vol. 4 no. 1, pp. $60-81$.

Heaslip G., Sharif A.M., Althonayan A. (2012), Employing a systems-based perspective to the identification of inter-relationships within humanitarian logistics, „International Journal of Production Economics", vol. 139 no. 2, pp. 377-392.

Hicks E., Pappas G. (2006), Coordinating disaster relief after the South Asia earthquake, „Society and Business Review", vol. 43 no. 5, pp. 42-50.

Houben, M. (2009), Hurricane alert. Hurricane relief operations in the Caribbean, Maritime Operations Working Paper No. 3.

Jahre M., Jensen L.M. (2010), Coordination in humanitarian logistics through clusters, „International Journal of Physical Distribution and Logistics Management”, vol. 40 no. 8/9, pp. 657-674.

Jensen L-M., Hertz S. (2016), The coordination roles of relief organisations in humanitarian logistics, „Journal of Logistics Research and Applications”, vol. 19 no. 5, pp. 465-485.

Kovács G., Spens K.M. (2007), Humanitarian logistics in disaster relief operations, „International Journal of Physical Distribution \& Logistics Management”, vol. 37 no. 2, pp. 99-114.

Kovács G., Spens, K.M. (2009), Identifying challenges in humanitarian logistics, „International Journal of Physical Distribution \& Logistics Management”, vol. 39, no. 6, pp. 506-528.

Kovács G., Spens K.M. (2011), Trends and developments in humanitarian logistics - a gap analysis, „International Journal of Physical Distribution \& Logistics Management”, vol. 41 no. 1, pp. 32-45.

Kovács, G., Tatham P.H. (2009), Responding to disruptions in the supply network. From dormant to action, „Journal of Business Logistics”, vol. 30 no. 2, pp. 215-229. 


\section{SAVING LIVES WITH FEWER DISCUSSIONS}

Leiras A., de Brito I. Jr, Peres E.Q., Bertazzo T.R., Yoshizaki H.T.Y. (2014), Literature review of humanitarian logistics research. Trends and challenges, „Journal of Humanitarian Logistics and Supply Chain Management", vol. 4, no. 1, pp. 95-130.

Listou T. (2011), How to supply a frigate, ,International Journal of Physical Distribution and Logistics Management”, vol. 43 no. 2, pp. 134-147.

McLachlin R., Larson P.D. (2011), Building humanitarian supply chain relationships. Lessons from leading practitioners, „Journal of Humanitarian Logistics and Supply Chain Management”, vol. 1 no. 1, pp. 32-49.

Moshtari M., Gonçalves P. (2016), Factors influencing interorganizational collaboration within a disaster relief context, „Voluntas. International Journal of Voluntary and Nonprofit Organizations”, vol. 28 no. 4, pp. 1673-1694.

Nolte I.M., Martin E.C., Boenigk S. (2012), Cross-sectorial coordination of disaster relief, „Public Management Review", vol. 14 no. 6, pp. 707-730.

Office for the Coordination of Humanitarian Affairs (OCHA) (2007), Oslo Guidelines, guidelines of the use of foreign military and civil defence assets in disaster relief, The Publishing Service, United Nations, Geneva.

Oloruntoba R. (2005), A wave of destruction and the waves of relief. Issues, challenges and strategies, „Disaster Prevention and Management”, vol. 14, pp. 506-521.

Paschal M.D. (2012), Getting beyond "good enough" in contingency contracting by using public procurement law as a force to fight corruption, „Contracting and Military Operations”, vol. 213, pp. 65139.

Pettit S., Beresford A. (2005), Emergency relief logistics. An evaluation of military, non-military and composite response models, „International Journal of Logistics: Research and Applications”, vol. 8 no. 4, pp. 313-331.

Pettit S., Beresford A. (2009), Critical success factors in the context of humanitarian aid supply chains, „International Journal of Physical Distribution \& Logistics Management”, vol. 39 no. 6, pp. 450-468.

Rietjes S.J.H. (2008), Managing civil-military cooperation: experiences from the Dutch provincial reconstruction team in Afghanistan, „Armed Forces \& Society”, vol. 34 no. 2, pp. 173-207.

Rietjens S.J.H., Voordijk H., De Boer S.J. (2007), Coordinating humanitarian operations in peace support missions, „Disaster Prevention and Management”, vol. 16 no. 1, pp. 56-69.

Rowley J. (2002), using case studies in research, „Management Research News”, vol. 25 no. 1, pp. 1627.

Rutner S., Avelis M., Cox S. (2012), Logistic evolution. A comparison of military and commercial logistic thought, „The International Journal of Logistics Management”, vol. 23 no. 1, pp. 96-118.

Schultz S.F., Blecken A. (2010), Horizontal cooperation in disaster relief logistics. Benefits and impediments, „International Journal of Physical Distribution and Logistics Management”, vol. 40 no. 8/9, pp. 636-656. 


\section{Johan STEVENS, Janjaap SEMEIJN, Cees J. GELDERMAN}

Schulz S.F., Heigh I. (2009), Logistics performance management in action within a humanitarian organization, „Management Research News”, vol. 32 no. 11, pp. 1038-1049.

Simatupang T.M., Victoria Sandroto I., Lubis H.S.B. (2004), Supply chain coordination in a fashion firm, „Supply Chain Management: An International Journal”, vol. 9 no. 3, pp. 256-268.

Tatham P., Houghton L. (2011), The wicked problem of humanitarian logistics and disaster relief aid, „Journal of Humanitarian Logistics and Supply Chain Management”, vol. 1 no. 1, pp. 15-31.

Tatham P.H., Pettit S.J. (2010), Transforming humanitarian logistics. The journey to supply network management, „International Journal of Physical Distribution and Logistics Management”, vol. 40, no. 8/9, pp. 609-622.

Tatham P., Rietjens S. (2016), Integrated disaster relief logistics: a stepping stone towards viable civilmilitary networks?, „Disasters”, vol. 40 no. 1, pp. 7-25.

Thomas A., Kopczak L. (2005), From logistics to supply chain management. The path forward in the humanitarian sector, Fritz Institute, www.fritzinstitute.org/PDFs/WhitePaper/FromLogisticsto.pdf [25.01.2017].

Thomas A., Mizushima M. (2006), Logistics training. Necessity or luxury?, „Forced Migration Review", no. 22, pp. 60-61.

Thompson W.C. (2010), Success in Kashmir. A positive trend in civil-military integration during humanitarian assistance operations, „Disasters”, vol. 34 no. 1, pp. 1-15.

UN/ISDR (2004), Living with risk. A global review of disaster reduction initiatives, https://www.unisdr.org/files/657_lwr1.pdf [31.05.2019].

Van Schoorl M. (2012), Natural disaster response in urban context, Final thesis MBA - Transport and Supply Chain Management".

Van Staa A.L., Evers J. (2010), Thick analysis. Strategie om de kwaliteit van kwalitatieve data-analyse te verhogen, „KWALON”, vol. 43 no. 1, pp. 5-12.

Van Wassenhove L.N. (2006), Humanitarian aid logistics. Supply chain management in high gear, „The Journal of Operations Research Society”, vol. 57 no. 7, pp. 475-489.

Vroemen M.W. (2009), Team op vleugels, Kluwer, Deventer.

Völz C. (2005), Humanitarian coordination in Indonesia. An NGO viewpoint, „Forced Migration Review", Special Issue, July 26-27, pp. 26-28.

Voss C., Tsikriktsis N., Frohlich M. (2002), Case research in operations management, „International Journal of Operations \& Production Management", vol. 22 no. 2, pp. 196-219.

Yin R.K. (2009), Case study research: design and methods, 4th edition, SAGE Publications, London.

Yin R.K. (2013), Case study research design and methods, 5th edition, SAGE Publications, London. 


\section{Appendix A: Interview guide}

Organisatieniveau: Strategisch (S), Tactisch (T) of Operationeel (O)

\begin{tabular}{|l|l|l|l||l|l|l|l|l||l||l||l|}
\hline & M & M & N & N & N & N & M & N & M & M & M \\
il & il & o & o & o & o & il & o & il & il & il \\
i & i & n & n & n & n & i & n & i & i & i \\
t & t & - & - & - & - & t & - & t & t & t \\
a & a & M & M & M & M & a & M & a & a & a \\
r & r & il & il & il & il & r & il & r & r & r \\
y & y & i & i & i & i & y & i & y & y & y \\
r & r & t & t & t & t & r & t & r & r & r \\
\hline s & & s & S\&T & S\& & T & T & T & T\&O & T\&O & o & o \\
\hline
\end{tabular}

1. Opening

1.1 (Hurricane Matthew)?

2. Timeliness

Was there a request for help formulated and where did it came from

2.1 (country/UN)?

How soon after the occurence of the disaster did you receive the request for 2.2 help?

2.3 How did your organization react/respond to it?

What actions were needed to get the necessary assets/goods in the disaster

2.4 area and how long did it take to get there?

2.5 Which assets/goods were needed for the help/assistance/operation?

3. Appropriateness

3.1 Did you conduct any sort of needs assessment?

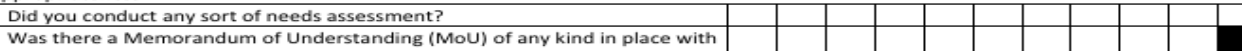
the country in which the emergency aid was conducted in case of legal

3.2 liability?

3.3 Are you familiar with the Oslo Guidelines?

Were the Oslo Guidelines leading in the coordination (with the Dutch military

3.4 forces or with the non-military organizations)?

4. Absorptive Capacity

What type of help/assistance did your organization deliver and when was this

4.1 help/assistance in place?

Did your organization have direct contact with the Haitian (local) authorities

4.2 or was it channelled through other agencies/organizations?

5. Efficiency

5.1 For how long did your organization deliver the help/assistance?

Was the emergency aid in accordance with the request or did it take

5.2 longer/shorter?

Was there any help/assistance rejected? And if so, what was the reason of 5.3 the rejection?

Was your organization able to provide all the requested help/assistance? of 5.4 were there some assets/goods not available?

Were there any problems with the coordination with the (Dutch military or

5.5 non-military (humanitarian) relief organizations during the relief operation? 6. Coördination

Were there any mechanisms in place for coordinating your efforts with other 6.1 providing countries, international agencies or the recipient country?

6.2 How effective was this coordinating mechanism and why?

Was the help/support/assistance of the different humanitarian aid

6.3 organizations complementary or did the in some cases overlap?

Is there any difference between the coordination with the (Dutch) military

6.4 organization and a humanitarian aid/relief organization?

6.5 How effective was the coordination in your opinion?

How do you evaluate the contribution of help/assistance? What are/were the

6.6 'lesssons learned'?

7. Costs

7.1 Are you familiar with the costs of this disaster relief operation?

7.2 Do you know how it was funded?

How do you evaluate the efficiency of the operation when you focus on the

7.3 coordination with the (Dutch military or non-military) organizations? 8. Concluding

What is your opinion on the role of a military organization during disaster

8.1 relief operations?

8.2 Do you have any last comments/remarks and/or additional comments?

$\mathrm{S}=$ Strategic leve

$\mathrm{T}=$ Tactical level

$\cap-$ nnorational laval 
Johan STEVENS, Janjaap SEMEIJN, Cees J. GELDERMAN

$\begin{array}{lll}\text { MoFA } & : & \text { Ministry of Foreign Affairs } \\ \text { NATO } & : & \text { North Atlantic Treaty Organization } \\ \text { (i)NGO } & : & \text { (international) Non-Governmental Organization } \\ \text { OCHA } & : & \text { Office for the Coordination of Humanitarian Affairs } \\ \text { PAHO } & : & \text { Pan-American Health Organization } \\ \text { SIPRI } & : & \text { Stockholm International Peace Research Institute } \\ \text { UK } & : & \text { United Kingdom } \\ \text { UN } & : & \text { United Nations } \\ \text { UNDAC } & : & \text { United Nations Disaster Assessment Coordination } \\ \text { US(A) } & : & \text { United States (of America) } \\ \text { WASH } & : & \text { Water, Shelter and Hygiene } \\ \text { WFP } & : & \text { World Food Program }\end{array}$

